\title{
Effect of water stress induced by polyethylene glycol 6000 on the somatic embryos conversion into whole plantlets in cocoa (Theobroma cacao L.)
}

\author{
Tokpapon Eliane MANLÉ ${ }^{1,2 *}$, Kan Modeste KOUASSI ${ }^{3}$, Brahima André SOUMAHORO ${ }^{4}$, \\ Tchoa KONÉ ${ }^{2}$, Kouablan Edmond KOFFI ${ }^{1}$ and Mongomaké KONÉ ${ }^{2}$
}
${ }^{1}$ Laboratoire Central de Biotechnologie (LCB), Centre National de Recherche Agronomique (CNRA), 01 BP 1740 Abidjan 01, Côte d'Ivoire.
${ }^{2}$ Laboratoire de Biologie et Amélioration des Productions Végétales, UFR Sciences de la Nature, Université Nangui Abrogoua d'Abidjan, 02 BP 801 Abidjan 02, Côte d'Ivoire.
${ }^{3}$ Laboratoire de Biotechnologie, Agriculture et Valorisation de Ressources Naturelles, UPR de Physiologie et Pathologie Végétales, Université Félix Houphouët-Boigny d'Abidjan, 08 BP 1085 Abidjan 08, Côte d'Ivoire. ${ }^{4}$ Section SVT, Ecole Normale Supérieure d'Abidjan, 08 BP 10 Abidjan 08, Côte d'Ivoire.
${ }^{*}$ Corresponding author; E-mail: elianemanle@gmail.com; Tel. +2250545263548

Received: 14-11-2020

Published: 28-02-2021

\begin{abstract}
Rainfall scarcity due to climate change is a major constraint that limits cocoa productivity in Côte d'Ivoire. This work aims to regenerate cocoa plants tolerant to water stress using in vitro methods. Staminode and petal explants of the genotypes $\mathrm{C} 1, \mathrm{C} 9, \mathrm{C} 14, \mathrm{C} 15, \mathrm{C} 16, \mathrm{C} 18$ and $\mathrm{C} 20$ were used to produce somatic embryos through two methods. Firstly, somatic embryos were induced under stressfull conditions on media containing different concentrations of polyethylene glycol (PEG) $6000(0 ; 25 ; 50 ; 75 ; 100$ and $125 \mathrm{~g} / \mathrm{l})$ and secondly; under non-stressed conditions. Somatic embryos were placed on a conversion medium in the same stress condition. The number of regenerants decreased with the increase in the concentration of PEG with all genotypes. Only genotypes $\mathrm{C} 1$ and $\mathrm{C} 15$ regenerated plantlets under water stress conditions. The sensitive genotypes C9, C14, C16, C18 and C20 have not developed plantlets on media containing PEG. The plantlets produced under water deficit conditions exhibited a reduction in stem length and leaves number and an increase in length or offset of the high number of roots. The survival rate of regenerants during acclimatization was higher on the sand substrate. The selected genotypes could be used in an improvement program of cocoa production.
\end{abstract}

(C) 2021 International Formulae Group. All rights reserved.

Keywords: Climate change; plant regeneration; genotype; tolerance; drought; in vitro.

\section{INTRODUCTION}

Drought is one of the most significant abiotic factors around the world that hinders the productivity of agricultural crops. Even in tropical areas, where annual rainfall is high, the soil's water capacity can decrease significantly during the dry season and affect the growth of the plant, especially cocoa (Läderach et al., 2013; Gateau et al., 2018). Cocoa cultivation is of great importance in economies of many countries. This sector creates jobs to the population on plantations and in processing 
plants. World cocoa production is carried out by Africa, Asia and Latino America. Côte d'Ivoire is the largest world producer with $41 \%$ of global supply (ICCO, 2020). Cocoa is a tropical plant. Water resources are important elements for its production (Schwendenmann et al., 2010).

However, the climate variability that the world is facing is causing droughts, particularly in tropical and subtropical regions. Many modeling studies predict that climate change will have a negative effect on cocoa productivity (Bunn et al., 2017). Drought is considered as the most devastating environmental stress to the cocoa tree, reducing crop productivity more than any other environmental stress (Kanohin et al., 2012). The displacement from the original cocoa producing regions to new areas could have the effect of intensifying deforestation in tropical areas such as Côte d'Ivoire (Ruf et al., 2015). Identification of tolerant genetic material to water deficit appears to be an alternative solution to reduce the impact of climate change on cocoa. However classical methods usually used for the selection of varieties tolerant to water deficit are limited by the long selection time and especially by the influence of several other environmental factors. In this context, plant biotechnology techniques and more particularly in vitro tissue culture can play important role in the selection of new varieties in addition to conventional field breeding. In in vitro culture conditions, only the cell from the whole plant is the target of selective pressures in order to achieve a range of regenerated variants that differ from those resulting from conventional breeding (Cattevilli et al., 2002). This results in a different genetic expression of cells cultured in vitro. Application of stress enables either a screening of the cells with natural elimination of the non-tolerant ones, or an adaptation with evolution of the basic potentialities but without elimination, thus directing the variability of the regenerants towards a tolerance to the exerted pressures. Stress-tolerant varieties have been identified in several plant species in vitro (Hassan et al., 2004; Errabii et al., 2006). Selection by in vitro culture with a single source of variability seems the most appropriate way to obtain droughttolerant varieties and thus mitigate the effect of climate change on the cocoa-orchard.

Therefore, the present work aimed to regenerate tolerant plants to water stress under in vitro conditions in some elite cocoa (Theobroma cacao L.).

\section{MATERIALS AND METHODS Experimental site}

The research station of National Center of Agronomic Research (CNRA) of Adiopodoumé (Laboratory Central of Biotechnology) located in Abidjan (Côte d'Ivoire), with geographical coordinates $4^{\circ} 7^{\prime}$ West and $5^{\circ} 20^{\prime}$ North was the study site. The climate is sub-equatorial. The average monthly temperature is $26.2 \pm 2{ }^{\circ} \mathrm{C}$. The relative humidity is between 80 and $90 \%$. Potential evapotranspiration (Turkish FTE) is 1.220 $\mathrm{mm} /$ year. The rainfall is high $(1,600$ to 2,700 $\mathrm{mm}$ with an average of $2,100 \mathrm{~mm} /$ year).

\section{Plant materials}

The plant material consisted of matures somatic embryos of seven elites genotypes of cocoa from CNRA of Côte d'Ivoire (C1, C9, $\mathrm{C} 14, \mathrm{C} 15, \mathrm{C} 16, \mathrm{C} 18$ and C20). These somatic embryos were obtained either under water deficit conditions induced by PEG 6000 and in conditions without any water deficit.

\section{Methods}

\section{Production of somatic embryos}

The methodology adopted to produce somatic embryos is that described by Kouassi et al. (2017). It consisted in cultivating the staminode and petal explants excised from the flower buds in Petri dishes containing $15 \mathrm{ml}$ of calli induction medium (IM). These flower buds were previously disinfected by immersion in a $1 \%(\mathrm{w} / \mathrm{v})$ sodium hypochlorite solution for $20 \mathrm{~min}$ followed by three rinses with sterile distilled water. They are again immersed successively in $70 \%(\mathrm{v} / \mathrm{v})$ alcohol for $30 \mathrm{~s}$, then in a $1 \%(\mathrm{w} / \mathrm{v})$ sodium hypochlorite containing two drops of tween 20 for $10 \mathrm{~min}$ and then rinsed three times with sterile distilled water. After four weeks of culture, the explants were transferred onto the embryo development 
medium (ED medium). Subculture of these explants on the ED medium takes place each four weeks. After eight weeks of culture on ED medium (ED, second subculture), the somatic embryos were isolated from the calli and transferred again onto ED medium for maturing.

\section{Preparation of culture media}

Calli induction medium (IM), embryo development medium (ED medium) and primary embryo conversion medium (PEC) used in this study were composed from stock solutions consisting of macro and micro elements of DKW (Driver and Kuniyuki, 1984). ED and PEC media were free of phytohormones contrary to IM culture media. However, the PEC medium was supplemented with KN03 and Amino Acid solution.

The $\mathrm{pH}$ of media was adjusted to 5.7 using solutions of $0.1 \mathrm{~N} \mathrm{NaOH}$ or $\mathrm{HCl}$. Culture media were solidified with Phytagel ( $2 \mathrm{~g} / \mathrm{l})$, and then autoclaved for $20 \mathrm{~min}$ at $121{ }^{\circ} \mathrm{C}$ under a pressure of 1 bar. After sterilization, IM and ED media aliquots of $15 \mathrm{ml}$ were dispensed in Petri dishes. For PEC medium, the distribution was done due to $25 \mathrm{ml}$ per jar before sterilization.

\section{Somatic embryos conversion on primary embryo conversion medium (PEC) under water deficit conditions}

Water stress was induced using two methods. First method consisted of producing callus and somatic embryos in water deficit conditions and converting these embryos to plantlets under the same conditions. For this purpose, increasing concentrations of PEG $6000(25,50,75,75,100$ and 125$)$ resulting respectively decreased water potentials $(-0.19$, $-0.5,-0.93,-1.48,-2.16 \mathrm{MPa})$ were added to the culture media (IM, ED and PEC) (Michel and Kaufmann, 1973). The second method concerned with embryos formation under nonstressed conditions (IM and ED without PEG). Conversion of somatic embryos to plantlets was then carried out in the presence of PEG concentrations as previously indicated on PEC medium.

Mature somatic embryos exhibiting well-developed caulinary and root poles on ED medium were transferred to jars containing 25 $\mathrm{ml}$ of PEC medium supplemented with PEG 6000. These cultures were then transferred to a culture room.

\section{Culture conditions}

All induced-somatic embryos media culture were randomly incubated in a growth chamber in continuous darkness for four weeks, at average temperature of day and night of $24{ }^{\circ} \mathrm{C} \pm 1{ }^{\circ} \mathrm{C}$ and at $70 \%$ relative humidity. For the conversion of somatic embryos into plantlets, cultures were transferred to a culture room under a photoperiodic cycle of $16 / 8 \mathrm{~h}$ (long days), a light intensity of 50 to $190 \mathrm{umol}$ $\mathrm{m}^{-2} \mathrm{~s}^{-1}$, at a temperature of $24 \pm 1{ }^{\circ} \mathrm{C}$ and a relative humidity of $70 \%$.

Evaluation of conversion rate of somatic embryos to plantlets

After twelve weeks of culture on PEC medium, the somatic embryos that had evolved to plantlets were counted. The rate of conversion of somatic embryos to plantlets (RCP) was calculated by the formula:

$$
\mathrm{RCP}=\frac{\mathrm{NP}}{\mathrm{NTE}} \times 100
$$

NP: Number of normal plantlets obtained

TNE: Total number of somatic embryos transferred on PEC medium

Evaluation of morphological parameters of the plantlets

The number of leaves and roots per regenerated plantlets were counted. The lengths of the main root and the stem of the regenerated plantlets were measured using a ruler.

\section{Acclimatization of regenerated plantlets}

Substrate preparation and transfer of plantlets

Regenerated Cocoa plants tolerant to water deficit induced by PEG 6000 having developed leaves and roots were delicately removed from the gelled media using tweezers so as not to damage the root system. The roots were then carefully washed with distilled water to remove the remaining gelose, then the plantlets were treated with fungicide (banko plus 50\%) for 30 sec. Banko plus is a combination of two active ingredients: Chlorothalonil $(550 \mathrm{~g} / \mathrm{l})$ used for prevention and acting by contact and Carbendazim (100 $\mathrm{g} / \mathrm{l})$ used as a curative and acting systemically. 
Plants were transferred into sterile plastic pots containing different substrates. The substrates consisted of arable land from the CNRA forest and fine sand from the Adiopodoumé lagoon with geographical coordinates $4^{\circ} 7^{\prime}$ West and $5^{\circ} 20^{\prime}$ North and located about $17 \mathrm{~km}$ west of Abidjan. These substrates were autoclaved for 1 hour at $121{ }^{\circ} \mathrm{C}$ under pressure of 1.5 bar. Then, the pots were randomly placed in bins (mini greenhouse) covered with a transparent plastic support. These pots have been previously punched at the base to avoid asphyxiation of the plants by excess water. Mini greenhouses were transferred to a culture room under a photoperiodic cycle of $16 / 8 \mathrm{~h}$ (long days), a light intensity of $50-190$ umol $\mathrm{m}^{-2} \mathrm{~s}^{-1}$, at a temperature of $24 \pm 1{ }^{\circ} \mathrm{C}$ and a relative humidity of $70 \%$. Weaned plants were watered regularly with sterile distilled water.

After two weeks of preliminary conditioning in laboratory, the jars containing the regenerants were transferred to the greenhouse at a temperature of around $38{ }^{\circ} \mathrm{C}$ and a relative humidity of about $92 \%$ and arranged randomly. They were covered with bottles for two weeks. Then, the bottle covering the pot was removed and the crops were kept acclimatized in the greenhouse for four weeks in the open air before being transferred. During this acclimatization period, the plants were watered regularly with tap water.

Evaluation of plantlet survival rates

Acclimatization was evaluated through the survival rate of regenerant at each acclimatization step. After two weeks of preaclimatization, a first evaluation of the number of viable regenerants was carried out. After six weeks of acclimatization in the greenhouse, a second evaluation of the number of viable plants was carried out. Survival rate (SR) of the regenerants were estimated according to the formula:

$$
\mathrm{RS}=\frac{\mathrm{NP}}{\mathrm{NTP}} \times 100
$$

NPV : number of survived plants.

NPT : total number of plantlets transferred.

\section{Data Analysis}

All experiments were repeated three times with six replicates by treatment for the conversion of somatic embryos to plantlets. The results were submitted to Analysis of variance (ANOVA) using the Statistica 7.1 software. The multiple rank test of NewmanKeuls at 5\% threshold was used to separate means. For the rate assessment, an Arc sin transformation ( $\mathrm{p}=$ proportion) was realized before performing the Analysis of variance.

\section{RESULTS \\ Effect of PEG 6000 on the development of somatic embryos}

The evolution of somatic embryos subjected to water stress induced by PEG 6000 is shown in Figure 1. The viability of somatic embryos produced decreased with the increase in the concentration of PEG in the culture media. The root and caulinary poles were not differentiated in embryos obtained on the medium containing the highest concentration of PEG 6000 (125 g/l). These different poles were atrophied at $100 \mathrm{~g} / \mathrm{l}$ of PEG 6000. Embryos obtained on media containing 0, 25, 50 and $75 \mathrm{~g} / 1$ PEG were viable.

In general, the increase in concentration of PEG 6000 in culture medium reduced the number of viable somatic embryos with incomplete and abnormal development.

\section{Effect of water stress on the conversion of cocoa somatic embryos into plantlets}

The conversion rate of viable somatic embryos developed on media supplemented with $0,25,50$ and $75 \mathrm{~g} / \mathrm{l}$ of PEG 6000 and transferred to the medium for conversion of somatic embryos into plantlets (PEC medium) containing the same concentrations of PEG 6000 are shown in Figure 2. Analysis of these results showed that only genotypes $\mathrm{C} 1$ and $\mathrm{C} 15$ developed plantlets on culture media containing PEG. The percentage of somatic embryos conversion in these genotypes was significantly higher in the control medium $(36.36 \%$ and $27 \%)$ than in the other media $(P<0,001)$. The lowest percentages were obtained on medium containing $50 \mathrm{~g} / \mathrm{l}$ PEG $6000(12.5 \%$ and $4.16 \%)$. The results showed 
that no conversion of embryos was observed on the medium containing $75 \mathrm{~g} / \mathrm{l}$ of PEG. In genotypes C14, C16 and C20, only somatic embryos grown on media without PEG 6000 were converted into plantlets. For all the embryo conversion media used, genotypes C9 and $\mathrm{C} 18$ did not develop plantlets.

According to these results, three groups of genotypes were identified. In the first group, genotypes $\mathrm{C} 1$ and $\mathrm{C} 15$ developed plants in the presence of PEG 6000. They were referred as water stress-tolerant. The second group contained genotypes $\mathrm{C} 14, \mathrm{C} 16$ and $\mathrm{C} 20$ which were embryogenic and sensitive to water stress. These genotypes only developed plantlets on the medium without PEG. Embryogenic and water stress-sensitive genotypes consisted of C9 and C18 have not developed any plantlet on all culture media used.

\section{Effect of water stress on the conversion of somatic embryos into plantlets from culture medium without PEG}

A comparison of cultures on the control medium and the media supplemented with PEG showed a weak tendency of the embryos to be converted into plantlets with the increase in the concentration of PEG. The genotypes reacted differently under these conditions (Figure 3). Only genotypes $\mathrm{C} 1$ and $\mathrm{C} 15$ have produced plantlets with concentrations ranging from 0 to $100 \mathrm{~g} / \mathrm{l}$ of PEG. Genotypes C14, C16 and $\mathrm{C} 20$ developed plantlets only in the control medium. In all the genotypes tested, no conversion of somatic embryos was observed on the medium containing $125 \mathrm{~g} / \mathrm{l}$ of PEG. On the other hand, in genotypes C9 and C18, whatever the medium used, the conversion of somatic embryos was inhibited.

These responses to conversion of somatic embryos enabled the genotypes to be classified in the same three groups as indicated before.

Genotypes $\mathrm{C} 1$ and $\mathrm{C} 15$ which showed good performance for somatic embryo conversion were selected for further work.

\section{Effect of PEG on morphological characteristics of regenerants tolerant to water deficit}

Figure 4 shows cocoa regenerants developed on PEC medium containing 0, 25, 50 and $75 \mathrm{~g} / \mathrm{l}$ of PEG 6000 from viable somatic embryos obtained under the same water stress conditions. The leaves, stem and roots of plantlets were well developed on PEC medium containing 25 g/l PEG 6000, (Figure 4b). As for the medium containing $50 \mathrm{~g} / \mathrm{l}$ PEG 6000 , the leaves of plantlets were fleshy with reduced roots (Figure 4c). Plantlets obtained on the medium containing $75 \mathrm{~g} / \mathrm{l}$ of PEG 6000 were not-viable. They did not develop roots and the leaves were very reduced (Figure 4d).

Figure 5 showed plantlets regenerated from somatic embryos produced under nonstressed condition and later cultivated on the PEC media with 0, 25, 50 and 75, 100 and 125 $\mathrm{g} / \mathrm{l}$ of PEG 6000 . The plantlets obtained on the media supplemented with 25, 50, 75 and 100 $\mathrm{g} / \mathrm{l}$ of PEG 6000 had the open leaves and welldeveloped roots (Figure 5b, c, d and e). Low growth of plantlets was recorded on the medium containing $125 \mathrm{~g} / \mathrm{l}$ PEG 6000. These plantlets had only the main root and cotyledonary leaves (Figure 5f).

Morphological characteristics of the plantlets obtained under water stress conditions induced by PEG are shown in Table 1. There was a variation according to genotype and concentration of PEG. A decrease in the number of leaves was recorded with the increase in the concentration of PEG in the culture medium in genotypes $\mathrm{C} 1$ and $\mathrm{C} 15$. The high number of leaves (7.6 and 7.3) was obtained with regenerants of the genotype $\mathrm{C} 1$ developed respectively on the control medium and the medium with $25 \mathrm{~g} / \mathrm{l}$ of PEG (from somatic embryos produced on media containing the same concentration of PEG). A reduction in stem length with increasing PEG concentration was also recorded in both types of regenerants.

The longest stem length was recorded with genotype $\mathrm{C} 1$ on the control medium (5.3 $\mathrm{cm})$. The number of roots of the plantlets increased significantly with the concentration of PEG in both genotypes compared to the 
control medium. The highest average root number $(27.8 \mathrm{~cm})$ was obtained on the medium supplemented with $25 \mathrm{~g} / \mathrm{l}$ PEG with somatic embryos of genotype $\mathrm{C} 1$ produced under water stress condition. The lowest number of root was recorded with the genotype $\mathrm{C} 15$ on the medium containing $50 \mathrm{~g} / \mathrm{l}$ PEG from embryos obtained under the same conditions. The length of the main root of regenerants varied in both genotypes when the concentration of PEG was high in the culture medium. Longest roots (8.4 $\mathrm{cm}$ ) were recorded in regenerants of genotype $\mathrm{C} 1$ on the medium containing $25 \mathrm{~g} / 1$ of PEG from embryos obtained under water stress conditions. Shortest roots were produced by genotype $\mathrm{C} 15$ on medium containing $50 \mathrm{~g} / \mathrm{l}$ from somatic embryos obtained in the same conditions as before.

Analysis of the morphological adaptation characteristics of the regenerants obtained under water stress conditions compared to the controls revealed: (i) a decrease in the number of leaves with the increased concentration of PEG 6000; (ii) an increase in root length or compensation by increase the number of roots with the level of stress applied and (iii) a reduction in the length of the stems with the increase in PEG concentration.

\section{Acclimatization of plantlets}

Table 2 shows the survival rate of regenerants after two weeks of preacclimatization in a mini greenhouse on two substrates (topsoil and fine sand) in the laboratory and six weeks of acclimatisation in the greenhouse. Plantlets growth was observed on the fine sand during pre-acclimation, while no regenerant survival was noted on the arable land. These plantlets were damaged by fungi. Survival rate of plantlets on the sand of both genotypes was very high ( $89 \%$ for genotype $\mathrm{C} 1$ and $88 \%$ for $\mathrm{C} 15$ ) in the laboratory. Experimental results showed that the survival rate of regenerants after Acclimatization in the greenhouse was high compared to mortality in both genotypes. This rate was $87 \%$ for genotype $\mathrm{C} 1$ and $86 \%$ for $\mathrm{C} 15$.
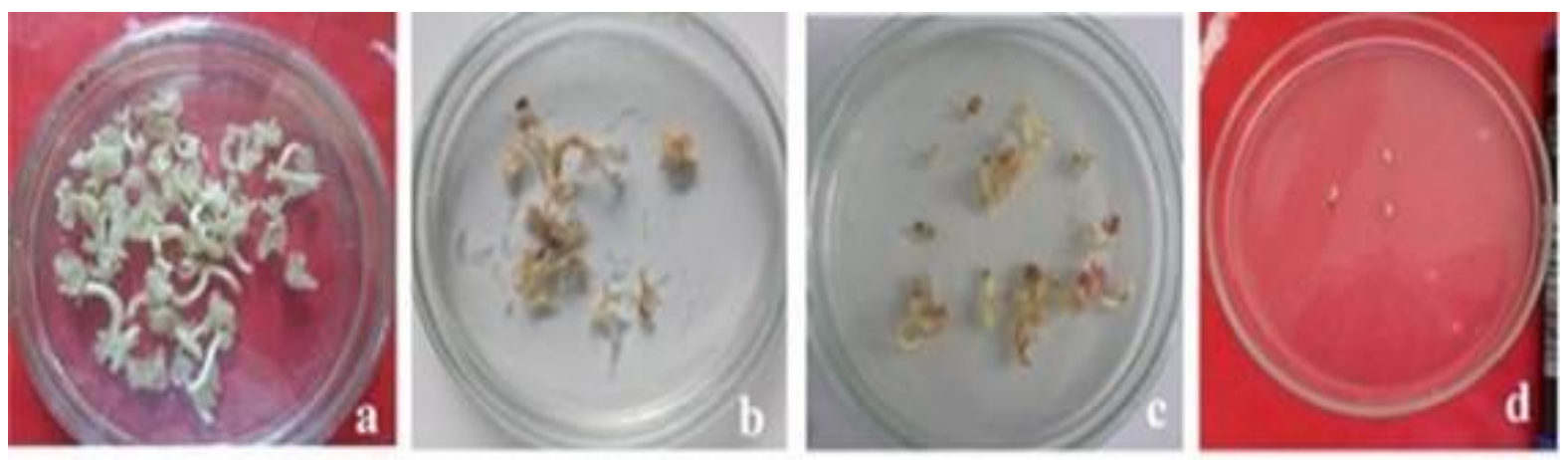

Figure 1: Development of somatic embryos on ED medium supplemented with PEG after one month of isolation. a- well-developed somatic embryos on culture medium without PEG; b- low growth of somatic embryos on culture medium containing $75 \mathrm{~g} / \mathrm{l}$ of PEG ; c-atrophied somatic embryos on medium containing $100 \mathrm{~g} / \mathrm{l}$ of PEG ; d-necrosed somatic embryos on the medium containing $125 \mathrm{~g} / \mathrm{l}$. 


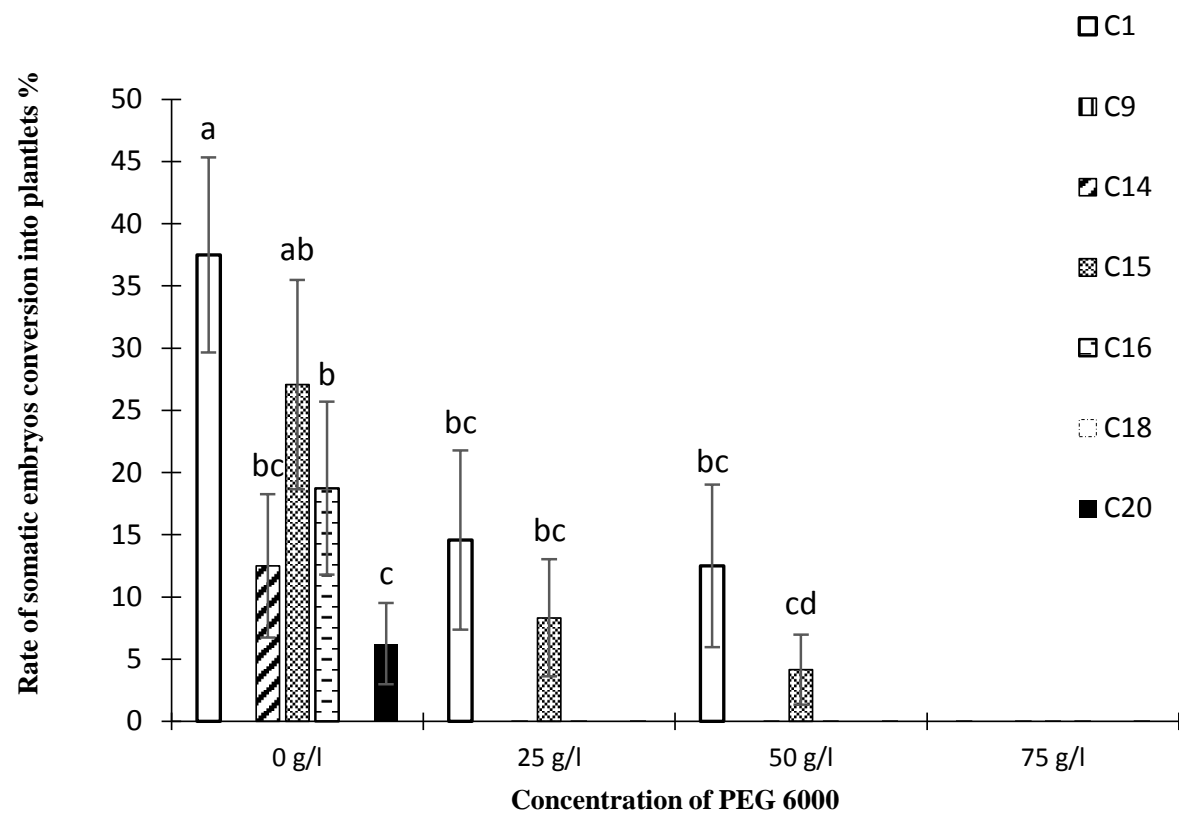

Figure 2: Conversion rate of somatic embryos into plantlets according to concentration of PEG. a,b,c,d: Bars with the same letter have the same conversion rates.

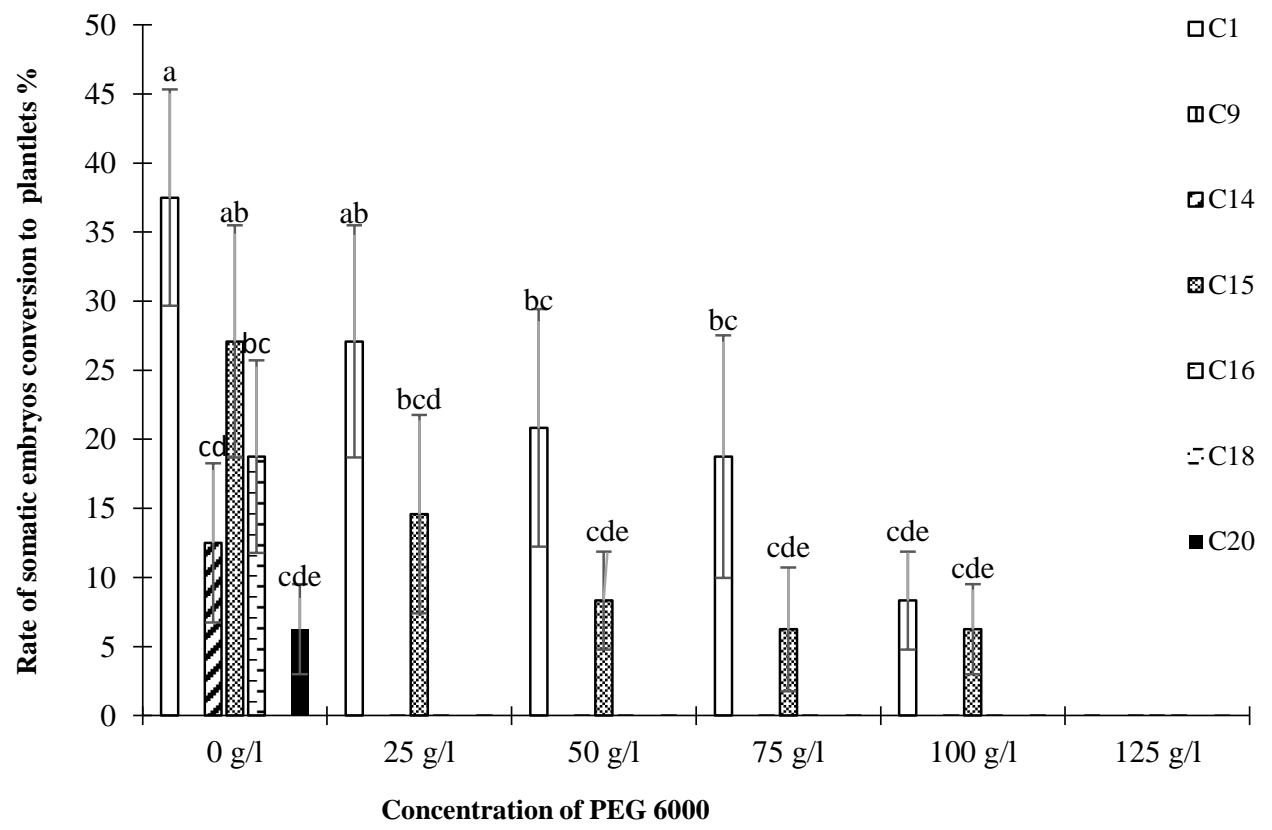

Figure 3: Conversion rate of somatic embryos obtained in non-stressed condition to plantlets according to concentration of PEG. a,b,c,d,e: Bars with the same letter have the same conversion rates. 

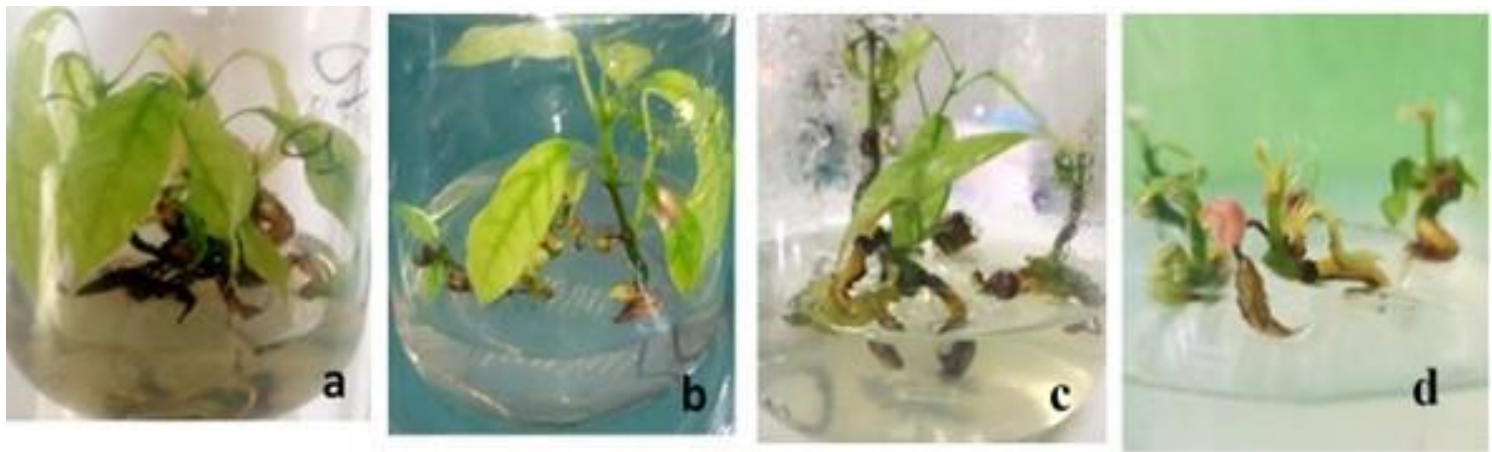

Figure 4 : Conversion of somatic embryos induced in medium supplemented with PEG 6000 into whole plantlets with growth affected by water stress. a-control medium; b-25 g/l PEG 6000; c-50 g/IPEG 6000 ; d-75 g/l PEG 6000.
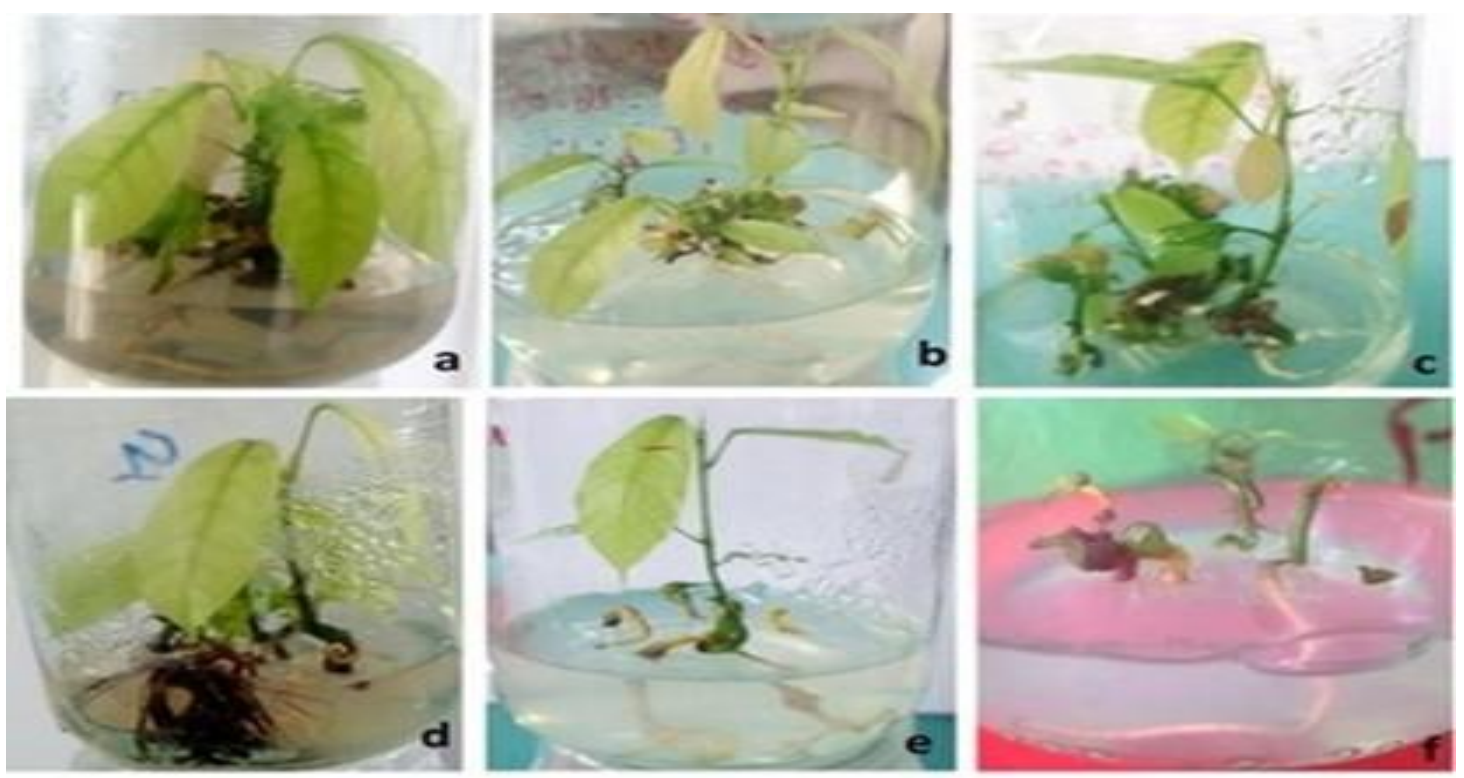

Figure 5 : Conversion of somatic embryos induced under non-stressed condition into whole plantlets with growth affected by water stress induced by PEG 6000. a-control medium; b-25 g/l PEG 6000; c-50 g/l PEG 6000 ;75 g/l PEG 6000; e-100 g/l PEG 6000; f-125 g/l PEG 6000. 
Table 1: Morphological parameters of the selected plantlets.

\begin{tabular}{|c|c|c|c|c|c|}
\hline Genotypes & $\begin{array}{l}\text { Medium } \\
\text { (concentration } \\
\text { of PEG mg/l) }\end{array}$ & $\begin{array}{l}\text { Average } \\
\text { number of } \\
\text { leaves }\end{array}$ & $\begin{array}{l}\text { Average } \\
\text { number of } \\
\text { roots }\end{array}$ & $\begin{array}{l}\text { Average } \\
\text { length of } \\
\text { roots }(\mathrm{cm})\end{array}$ & $\begin{array}{l}\text { Stem average } \\
\text { length }(\mathrm{cm})\end{array}$ \\
\hline \multirow{7}{*}{$\mathrm{C} 1$} & $\mathrm{M}_{0}$ & $7.66 \pm 0.2^{\mathrm{a}}$ & $5.5 \pm 0.2^{c}$ & $6.1 \pm 0.6^{b}$ & $5.3 \pm 0.4^{\mathrm{a}}$ \\
\hline & $\mathrm{M}_{25}$ & $5.9 \pm 0.4^{\mathrm{c}}$ & $5 \pm 1.3^{c}$ & $3.8 \pm 0.2^{\mathrm{d}}$ & $4.6 \pm 0.5^{\mathrm{ab}}$ \\
\hline & $\mathrm{M}_{50}$ & $5.9 \pm 0.0^{c}$ & $8.5 \pm 0.0^{\mathrm{b}}$ & $2.8 \pm 0.0^{\mathrm{de}}$ & $4.1 \pm 0.0^{\mathrm{b}}$ \\
\hline & $\mathrm{M}_{75}$ & $5.7 \pm 0.0^{\mathrm{cd}}$ & $9.6 \pm 3.0^{\mathrm{b}}$ & $2.5 \pm 0.3^{\mathrm{de}}$ & $3.4 \pm 0.3^{\mathrm{bc}}$ \\
\hline & $\mathrm{M}_{100}$ & $5.1 \pm 0.1^{\mathrm{d}}$ & $8.1 \pm 0.0^{\mathrm{b}}$ & $5.5 \pm 0.0^{\mathrm{bc}}$ & $3.2 \pm 0.0^{\mathrm{bc}}$ \\
\hline & $\mathbf{M}_{25 / 25}$ & $7.3 \pm 0.5^{\mathrm{ab}}$ & $27.8 \pm 3.8^{\mathrm{a}}$ & $8.3 \pm 0.6^{\mathrm{a}}$ & $3.8 \pm 0.6^{\mathrm{bc}}$ \\
\hline & $\mathrm{M}_{50 / 50}$ & $4.2 \pm 0.5^{\mathrm{de}}$ & $2.0 \pm 0.3^{\mathrm{d}}$ & $2.2 \pm 0.3^{\mathrm{de}}$ & $3.5 \pm 0.5^{\mathrm{bc}}$ \\
\hline \multirow{7}{*}{$\mathrm{C} 15$} & $\mathrm{M}_{0}$ & $7.0 \pm 0.3^{\mathrm{ab}}$ & $2.5 \pm 0.1^{\mathrm{cd}}$ & $2.4 \pm 0.1^{\mathrm{de}}$ & $4.3 \pm 0.6^{\mathrm{ab}}$ \\
\hline & $\mathrm{M}_{25}$ & $4.2 \pm 0.2^{\mathrm{de}}$ & $3.5 \pm 0.3^{\mathrm{cd}}$ & $2.1 \pm 0.2^{\mathrm{de}}$ & $3.7 \pm 0.5^{\mathrm{bc}}$ \\
\hline & $\mathrm{M}_{50}$ & $4.1 \pm 0.1^{\mathrm{de}}$ & $3.5 \pm 0.4^{\mathrm{cd}}$ & $2.0 \pm 0.0^{\mathrm{de}}$ & $3.2 \pm 0.2^{\mathrm{bc}}$ \\
\hline & $\mathrm{M}_{75}$ & $4.0 \pm 0.2^{\mathrm{e}}$ & $3.9 \pm 0.3^{\mathrm{cd}}$ & $1.8 \pm 0.1^{\mathrm{e}}$ & $3.0 \pm 0.5^{\mathrm{c}}$ \\
\hline & $\mathrm{M}_{100}$ & $3.5 \pm 0.2^{\mathrm{ef}}$ & $4.5 \pm 0.8^{\mathrm{cd}}$ & $3.5 \pm 0.5^{\mathrm{d}}$ & $2.1 \pm 0.4^{\mathrm{d}}$ \\
\hline & $\mathrm{M}_{25 / 25}$ & $6.6 \pm 0.2^{\mathrm{b}}$ & $8.0 \pm 1.0^{\mathrm{b}}$ & $5.1 \pm 0.8^{c}$ & $4.3 \pm 0.2^{\mathrm{ab}}$ \\
\hline & $\mathrm{M}_{50 / 50}$ & $3.3 \pm 0.3^{\mathrm{f}}$ & $1.3 \pm 0.1^{\mathrm{d}}$ & $1.6 \pm 0,0^{\mathrm{e}}$ & $2.6 \pm 0.1^{\mathrm{cd}}$ \\
\hline$P<$ & & 0.001 & 0.001 & 0.001 & 0.001 \\
\hline
\end{tabular}

In the same column, the means followed by the same letter are statistically equal (test of Newman-Keuls at 5\% threshold); mean \pm standard deviation; M1 to M6: Culture media realized with different concentration of PEG.

Table 2: Survival rate of cocoa plantlets on substrates in mini greenhouse and greenhouse after acclimatization.

\begin{tabular}{clcccc}
\hline \multirow{2}{*}{ Substrate } & Genotype & \multicolumn{2}{c}{ Pre- acclimatization } & \multicolumn{2}{c}{ Acclimatization in the greenhouse } \\
\cline { 2 - 6 } & $\begin{array}{l}\text { Mortality rate of } \\
\text { plantlets (\%) }\end{array}$ & $\begin{array}{l}\text { Survival rates } \\
\text { of plantlets (\%) }\end{array}$ & $\begin{array}{l}\text { Mortality rate } \\
\text { of plantlets (\%) }\end{array}$ & $\begin{array}{c}\text { Survival rates of } \\
\text { plantlets (\%) }\end{array}$ \\
\hline \multirow{2}{*}{ Sand } & $\mathrm{C} 1$ & 10,70 & 89,3 & 12,80 & 87,14 \\
\cline { 2 - 6 } & $\mathrm{C} 15$ & 11,80 & 88,20 & 13,45 & 86,55 \\
\hline \multirow{2}{*}{$\begin{array}{c}\text { Arable } \\
\text { land }\end{array}$} & $\mathrm{C} 1$ & 100 & 0 & $/$ & $/$ \\
\cline { 2 - 6 } & $\mathrm{C} 15$ & 100 & 0 & $/$ & $/$ \\
\hline
\end{tabular}




\section{DISCUSSION}

\section{Development of somatic embryos}

Conversion of somatic embryos into plantlets is one of the major challenges in somatic embryogenesis. In this study, the effect of water stress on the conversion into plantlets of somatic embryos from seven cocoa genotypes and their survival in greenhouses was evaluated. The results showed a reduction in the number and abnormal development of somatic embryos in all genotypes tested when PEG concentration in the culture medium was increased. The water deficit induced by the high concentrations of PEG in the culture medium would lead to a reduction in the yield of somatic embryos as well as incomplete development and anatomical abnormalities of the somatic embryos (Tereso et al., 2007). Somatic embryogenesis is a complex process of development that relies heavily on metabolisms of the elements such as carbohydrates and proteins (Iraqi and Tremblay, 2001). Importance of carbohydrate metabolism would be explained by the high energy demand required for the metabolic processes that occur during cell division and elongation for the development of embryonic tissue (Cangahuala-Inocente et al., 2009). Gradual reduction in the development of somatic embryos on culture media with the increase in the concentration of PEG would be due to the insufficient quantity of sugar in embryogenic calli. External osmotic potential reduced by the PEG would have limited the absorption of water and nutrients from the external environment (sugars) necessary for embryos development. Thus, the works reported by Iraqi and Tremblay (2001) on Picea glauca and Rode et al. (2011) on Cyclamen persicum have shown the importance of sugars in the processes of embryo development. Moreover, the water deficit in the extracellular medium induced by the high concentrations of PEG would have favoured an excessive outflow of water from the cytoplasm and vacuoles of the embryonic cells. Cell plasmolysis would have inhibited cellular metabolism. This would cause damage to these embryonic cells and lead to necrosis in them.
When concentration of PEG was low $(25,50$ and $75 \mathrm{~g} / \mathrm{l})$ in the culture medium, normal somatic embryos were produced. Embryonic tissues would have developed a mechanism of tolerance to induced water stress. Genotypes $\mathrm{C} 1$ and $\mathrm{C} 15$ would have higher potentials to control the effect of water stress unlike other genotypes. Plant cells can acquire their stress-resistance capacity at different stages of development during in vitro cultures (Tewary et al., 2000). This response of the somatic embryos can be attributed to genetic variability at the level of cocoa genotypes.

\section{Conversion des embryons somatiques en plantules}

In addition, the stress induced by PEG had adverse effects on the conversion of somatic embryos to plantlets in all the cocoa genotypes tested. Development of plantlets in genotypes $\mathrm{C} 1$ and $\mathrm{C} 15$ would be due to their ability to use water and nutrients from medium when the concentration of PEG 6000 is low. Genotypes $\mathrm{C} 1$ and $\mathrm{C} 15$ would have a gene that is tolerant of induced stress.

The lack of conversion of somatic embryos to plantlets of genotypes C14, C16 and $\mathrm{C} 20$ on stressed media and genotypes $\mathrm{C} 1$ and $\mathrm{C} 15$ on media containing $75 \mathrm{~g} / \mathrm{l}$ could be attributed to the presence of non-viable cells in the embryogenic calli or to the successive exposure of these somatic embryos to water stress. Necrosis of the cells under the effect of stress would have inhibited the development of somatic embryos to plantlets. The reduction in the number of seedlings from calli obtained under stress conditions has been shown in several plant species (Mengesha et al., 2016; Kacem et al., 2017). In addition, the effect of water stress on the reduction of cell division and elongation by loss of turgidity has been reported in work led by Jaleel et al. (2009). Adding PEG to the medium would cause cell dehydration by reducing the water availability of the cells. The loss of turgidity in the cells would lead to an imbalance in growth, which is damaging to cell differentiation (Beauzamy et al., 2014). 
When the embryos obtained under normal (non-stressed) conditions were grown on the conversion medium to plantlets supplemented with PEG, the number of regenerants was high. The embryos would have accumulated enough energy and nutrients on the previous medium. These reserves would be used by the tissues for the development of regenerants. However, the numbers of plants regenerated from the two methods of obtaining somatic embryos decreased with increasing concentration of PEG. A similar decrease in plantlet regeneration under conditions of in vitro stress has been reported in soybean (saepudin et al., 2017) and rice (Chakraborty et al., 2018). Tolerance capacity of genotypes $\mathrm{C} 1$ and $\mathrm{C} 15$ can be attributed to the activation of a gene for tolerance to induced stress. Indeed, the work carried out by Basu et al. (2016) on plants showed that drought resistance is linked to the capacity of a variety to develop a high number of adaptation mechanisms. The different regeneration performances of the genotypes under effect of the increasing PEG concentrations in the present study could be due to the genetic difference of the genotypes.

\section{Morphological characteristics of regenerants}

Effect of water stress can result in morphological changes in the cocoa at the first stage of development, which is an adaptive strategy to drastic conditions of short or longlasting drought (Carr and Lockwood, 2011; Padi et al., 2013). The presence of PEG in the regeneration medium had a detrimental effect on most of the parameters associated with plantlets regeneration. These variables responded differently to the stress. Indeed, stem length and the number of leaves have decreased in plants produced from the two methods of obtaining somatic embryos of genotypes $\mathrm{C} 1$ and $\mathrm{C} 15$ (obtained under stress or non-stress). These responses of genotypes would be typical of this stress. The water deficit would act in most plant species by slowing down the growth of aerial organs. The observed modifications would result from a decrease in the rate of division of the constituent cells of these organs and a modification of the physico-chemical properties of the cell walls which become more stiffened (Granier et al., 2000). In addition, drought causes osmotic and oxidative stress in plant cells, which would prevent their growth. Growth reduction would be a preventive response of regenerants to anticipate severe water stress events (Cosgrove, 2005). Benmahioul et al. (2017) observed a reduction in the leaf-number of Pistacia vera L. semiplants with the increase in the concentration of PEG in culture medium. Decrease in aerial part has been considered as a response or adaptation to the water deficiency in plants (Imorou et al., 2018). In this study, reduction of the number of leaves of the regenerants would be a strategy for these plants to tolerate water stress.

Root length increased or was compensated by the increase in root number in regenerants with the level of water stress in the growing medium. The highest number and longest roots were produced with genotype $\mathrm{C} 1$ on the medium containing the low concentration of PEG and from embryos produced under the same conditions. Root length is a valid criterion for the selection of drought-tolerant varieties in cocoa (Santos et al., 2016).

\section{Acclimatization}

In the present study, the process of acclimatization applied to regenerants obtained from stressed and unstressed embryos varied according to substrates used. The plants were planted on the sand and arable land of the forest. The results showed that none survived on the forest soil. The mortality of these plants was related to fungal contamination of the substrate. The high water retention capacity of the forest soil would have contributed significantly to the contamination and death of the plants transferred to this substrate. The moisture has favoured the proliferation of microorganisms such as fungi that have infected cocoa plantlets (Tony and Caroline, 2011). However, on the sand the percentage of survival of regenerants was high. The sand is porous. Water infiltrates easily. This would prevent contamination of the substrate. 


\section{Conclusion}

In this study, a gradual reduction in the total number of viable somatic embryos was observed with increasing PEG concentration in culture media in all genotypes. Conversion of the somatic embryos into plantlets made it possible to identify three groups of waterstressed cocoa three genotypes: (1) water stress tolerant genotypes $\mathrm{C} 1$ and $\mathrm{C} 15$ which regenerated plants under water-stress conditions with embryos obtained in stressed or non-stressed media; (2) sensitive and embryogenic genotypes $\mathrm{C} 14, \mathrm{C} 16$ and $\mathrm{C} 20$ that have only developed plantlets on medium without PEG 6000 and (3) sensitive and embryogenic genotypes containing C9 and C18 have not developed any plantlets whatever the culture medium used. For both types of somatic embryos tested, the percentage of plantlets was higher in the somatic embryos obtained on the medium without PEG. The numbers of plantlets were reduced with increase of PEG in the culture media in both types of somatic embryos (embryos obtained in non-stressed or stressed conditions). No development of regenerants was observed on medium containing $125 \mathrm{~g} / \mathrm{l}$ of PEG. With regard to morphological parameters, a decrease in the number of leaves and stem length was observed with the increase in the concentration of PEG 6000 in the culture medium in the tolerant genotypes ( $\mathrm{C} 1$ and $\mathrm{C} 15)$. An increase in the length of the main root or a compensation by the high number of roots was recorded in the regenerants with the increase in the concentration of PEG 6000 in the growing medium. For acclimatization, the survival rate was high on the sandy substrate with $86 \%$ and $87 \%$ in regenerates of the two genotypes $\mathrm{C} 15$ and $\mathrm{C} 1$.

\section{COMPETING INTERESTS}

All authors agree with the content of the manuscript. They declare no conflicts of interest regarding the publication of this paper.

\section{AUTHORS' CONTRIBUTIONS}

The protocol was written by TEM and MK. The experimental device was set up by TEM and KMK. The manuscript was written by TEM. The revision of the manuscript was done by all co-authors.

\section{ACKNOWLEDGEMENTS}

The funds for this work were graciously donated by International Center Research of Agroforestry (ICRAF) and National Centre of Agronomic Research (CNRA) of Ivory Coast.

\section{REFERENCES}

Basu S, Ramegowda V, Kumar A, Pereira A. 2016. Plant adaptation to drought stress. F1000Research, 5: 1554. DOI: https://doi.org/10.12688/f1000research.7 678.1

Beauzamy L, Nakayama N, Boudaoud A. 2014. Flowers under pressure: ins and outs of turgor regulation in development. An. Bot., 114: 1517-1533. DOI: https://doi.org/10.1093/aob/mcu187

Benmahioul B, Kaid-Harche M, Daguine F. 2017. Effet du stress hydrique osmotique sur la germination et la croissance in vitro du pistachier vrai (Pistacia vera L.). Agricul. For. J., 1(2): 99-103. DOI: https://doi.org/10.5281/zenodo.1148497

Bunn C, Lundy M, Castro F. 2017. Global climate change impacts on cocoa. International Symposium on Cocoa Research (ISCR), Lima, Peru, 13-17 November 2017, p. 1-11.

Cangahuala-Inocente GC, Steiner N, Maldonado SB, Guerra MP. 2009. Patterns of protein and carbohydrate accumulation during somatic embryogenesis of Acca sellowiana. Pesquisa Agrop. Brasil., 44(3): 217-224. DOI: http://dx.doi.org/10.1590/S0100204X2009000300001

Carr MKV, Lockwood G. 2011. The water relations and irrigations requirements of cocoa (Theobroma cocoa L.): A Review. Exp. Agricul., 47: 653-676. https://doi.org/10.1017/S0014479711000 421

Cattevelli L, Baldi P, Crossati N, Di Fonzo N, Stanca M. 2002. Chromosome regions and stress related sequences involved in resistance to abiotic stress in Triticeae. Plant Mol. Biol., 48: 649-665. DOI: 
https://doi.org/10.1023/a:101482440462 3

Chakraborty A, Chowdhury S, Haque Z Dash AK, Mosnaz ATMJ. 2018. In Vitro shoot regeneration of rice (Oryza sativa L.) varieties under artificial drought stress. The Agricult., 16(1): 55-64. DOI: https://doi.org/10.3329/agric.v16i1.3753 4

Cosgrove DJ. 2005. Growth of the cell wall. Nature Reviews Mol., 6: 850-861. DOI: https://doi.org/10.1038/nrm1746

Driver JA, Kuniyuki AH. 1984. In vitro propagation of paradox walnut root stock. Hort. Sci., 507-509.

Errabii T, Gandonou CB, Essalmani H, Abrini J, Idomar M, Senhaji NS. 2006. Growth, proline and ion accumulation in sugarcane callus cultures under droughtinduced osmotic stress and its subsequent relief. Afr. J. Biotech., 5: 1488-1493.

Gateau L, Tanner E, Rapidel B, Marelli J-P, Royaert S. 2018. Climate change could threaten cocoa production: Effects of 2015-16 El Niño-related drought on cocoa agroforests in Bahia, Brazil. PLOS ONE, 13(7): e0200454. DOI: https://doi.org/10.1371/journal.pone.020 0454

Granier C, Inzé D, Tardieu F. 2000. Spatial distribution cell division rate can be deduced from that of $\mathrm{P} 34^{\mathrm{cdc} 2}$ kinase activity in maize leaves grown in contrasting conditions of temperature and water status. Plant Physiol., 124: 13931402.

DOI: https://doi.org/10.1104/pp.124.3.1393

Hassan NS, Shaaban LD, Hashem EA, Eman ES. 2004. In Vitro Selection for Water Stress Tolerant Callus Line of Helianthus annus L. Cv. Myak. Inter. J. Agricul. Biol., 6(1): 13-18.

ICCO. 2020. Production of cocoa beans. Quarterly Bulletin of Cocoa Statistics, XLVI (1). Published: 06-03-2020.

Imorou L, Ahoton EL, Zoumarou-Wallis N, Kanlindogbe C. 2018. Water stress effect on agro-morphological and physiological parameters of three local cultivars of maize (Zea maysL.) of South Benin. Int.
J. Biol. Chem. Sci., 12(5): 2294-2308. DOI:

https://dx.doi.org/10.4314/ijbcs.v12i5.29

Iraqi D, Tremblay FM. 2001. Analysis of carbohydrate metabolism enzymes and cellular levels of sugars and proteins during spruce somatic embryogenesis suggests a regulator role ofexogenous sucrose in embryo development. J. Exp. Bot., 52(365): 2301-2311. DOI: 10.1093/jexbot/52.365.2301

Jaleel CA, Manivannan P, Wahid A, Farooq M, Somasundaram R, Panneerselvam R. 2009. Drought stress in plants: a review on morphological characteristics and pigments composition. Int. J. Agric. Biol., 11: $100-105$.

Kacem NS, Delporte F, Muhovski Y, Djekoun A, Watillon B. 2017. In vitro screening of durum wheat against water stress mediated through polyethylene glycol. $J$. Gen. Eng. Biotech., 15(1): 239-249. DOI:10.1016/j.jgeb.2017.04.004

Kanohin FO, Saley MB, Aké GE, Savané I. 2012. Variabilité climatique et productions de café et cacao en zone tropicale humide: cas de la région de Daoukro (Centre-est de la Côte d'ivoire). Inter. J. of Innov. Appl. Stud., 1(2): 194215.

Kouassi M K, Kahia J, Kouame NC, Mathias Tahi G. 2017. Comparing the effect of plant growth regulators on callus and somatic embryogenesis induction in four elite Theobroma cacao L. genotypes. Hort. Sci., 52(1): 142-145. DOI: https://doi.org/10.21273/HORTSCI1109 2-16

Läderach P, Martinez-Valle A, Schroth G, Castro N. 2013. Predicting the future climatic suitability for cocoa farming of the world's leading producer countries, Ghana and Côte d'Ivoire. Clim. Chan., 119(3-4): 841-854. DOI: https://doi.org/10.1007/s10584-0130774-8

Mengesha B, Mekbib F, Abraha E. 2016. In Vitro Screening of Cactus [Opuntia ficusindicia (L.) Mill] Genotypes for Drought Tolerance. Am. J. Plant Sci., 7: 1741- 
1758.

DOI:

http://dx.doi.org/10.4236/ajps.2016.7131 63

Michel BE, Kaufman RM. 1973. The osmotic potential of polyethylene glycol 6000 . Plant Physiol., 51: 914-916. DOI: https://dx.doi.org/10.1104\%2Fpp.51.5.91 4

Padi FK, Adu-Gyamfi P, Akpertey A, Alfred A, Ofori A. 2013. Differential response of cocoa (Theobroma cacao L.) families to field establishment stress. Plant Breed, 132(2): 229-236. DOI: https://doi.org/10.1111/pbr.12039

Rode C, Lindhorst K, Braun HP, Winkelmann T. 2011. From callus to embryo: A proteomic view on the development and maturation of somatic embryos in Cyclamen persicum. Planta, 235(5): 9951011. DOI: $10.1007 /$ S00425-01 1-1554-1

Ruf F, Schroth G, Doffangui K. 2015. Climate change, cocoa migrations and deforestation in West Africa: What does the past tell us about the future? Sustain. Sci., 10: 101-111. DOI: https://doi.org/10.1007/s11625-0140282-4

Saepudin A, Khumaida N, Sopandie D, Ardie SW. 2017. In Vitro Selection of Four Soybean Genotypes using PEG for Drought Tolerance. J. Agron. Indon., 45(1): 14-22. DOI: https://doi.org/10.24831/jai.v45i1.13749

Santos EA, Almeida A-AF, Ahnert D, White MCS, Valle RR, Baligar VC. 2016.
Diallel analysis and growth parameters as selection tools for drought tolerance in young Theobroma cacao plants. PLOS ONE, 11(8): e0160647. DOI: 10.1371/journal.pone. 0160647

Schwendenmann L, Veldkamp E, Moser G, Hölscher D, Köhler M, Clough Y, Anas I, Djajakirana G, Erasmi S, Hertel D, Leitner D, Leuschner C., Michalzik, B., Propastin, P, Tjoa A, Tscharntke T, van Straaten O. 2010. Effects of an experimental drought on the functioning of a cacao agroforestry system, Sulawesi, Indonesia. Glob. Change Biol., 16(5): 1515-1530. DOI: $10.1111 / \mathrm{j} .1365-$ 2486.2009.02034.x

Tereso S, Zoglauer K, Milhinhos A, Miguel C, Oliveira MM. 2007. Zygotic and somatic embryo morphogenesis in Pinus pinaster: Comparative histological and histochemical study. Tree Physiol., 27(5): 661-669.

DOI: 10.1093/treephys/27.5.661

Tewary PK, Sharma A, Raghunath MK, Sarkar A. 2000. In vitro response of promising mulberry (Morus sp) genotypes for tolerance to salt and osmotic stresses. Plant Growth Regul., 30: 17-21. DOI: https://doi.org/10.1023/A:1006297830318

Tony B, Caroline L. 2011. Les contaminations fongiques. La Lettre de l'OCIM, 138 : 4854. DOI: http://doi.org/10.4000/ocim.994 